\title{
Rodzina w II Rzeczypospolitej - jej główne zagrożenia ze strony chorób
}

Słowa kluczowe: rodzina, zachorowalność, dzieci, młodzież, II Rzeczpospolita (1918-1939)

Jesteśmy w okresie rocznicowych obchodów stulecia odzyskania niepodległości po latach rozbiorów. Różne uroczystości będą zapewne trwały kilka lat, gdyż dopiero rok 1923 przyniósł ostateczne zatwierdzenie kształtu II Rzeczypospolitej. Patrząc z naszej obecnej perspektywy widać wyraźnie, jak wraz z przebiegiem I wojny światowej przybliżał się czas zerwania zależności od zaborców. Coraz większe ustępstwa ze strony Niemiec i Austro-Węgier, postępujący kryzys i wreszcie rewolucja oraz wojna domowa w Rosji, a w końcu klęska wszystkich trzech zaborców umożliwiły jesienią $1918 \mathrm{r}$. „wybicie się na niepodległość”. Gdy w większości krajów zapanował już pokój, na ziemiach polskich dopiero w czerwcu $1921 \mathrm{r}$. skończyły się, toczone z różnym natężeniem, działania zbrojne trzeciego powstania śląskiego. Jedynie Pomorze Gdańskie i Zachodnia Małopolska z Krakowem nie doświadczyły okropieństw bezpośrednich działań zbrojnych, chociaż i tam wojna odcisnęła swoje tragiczne piętno. Trudno obecnie ustalić jakiś jeden decydujący fakt przesądzający o odzyskaniu suwerenności. Należy przyjąć cały łańcuch zdarzeń, począwszy od wybuchu ,wielkiej wojny” w 1914 r., przez najgroźniejszą dla naszego niezależnego bytu wojnę polsko-rosyjską, na ostatnich walkach na Śląsku 
kończąc. Cztery lata światowego konfliktu i niepełne trzy zwycięskich walk o niepodległość i granice przyniosły też niestety dużo ujemnych zjawisk $^{1}$. Wiele $\mathrm{z}$ nich negatywnie oddziaływało na polskie rodziny, rzutowało to nieraz na cały okres międzywojenny - aż do września 1939 r., jak choćby duża zachorowalność i śmiertelność spowodowana występowaniem wielu groźnych chorób, zwłaszcza w pierwszych latach niepodległości². Upływ czasu, bogata, stale zwiększająca się literatura przedmiotu, dostęp do źródeł powodują, że można obecnie, bez różnych uwarunkowań, zwłaszcza politycznych, ukazywać tamtą rzeczywistość w różnych barwach, nie zawsze zgodnych z potocznymi, obiegowymi ocenami, i badać najróżniejsze kwestie.

Warto przypomnieć, że w odrodzonej Rzeczypospolitej już w pierwszej Konstytucji z 17 marca 1921 r. zawarto artykuły mówiące o prawach i obowiązkach obywatelskich, odnoszące się do polskich rodzin, m.in. dające kobietom i mężczyznom równe prawa w wyborach do obu izb parlamentu (art. 12 i 36), nakładające na rodziców obowiązek właściwego wychowania i wykształcenia dzieci (art. 94), wprowadzające równość wobec prawa (art. 96) czy biorące pod ochronę dzieci, młodzież i kobiety ciężarne w wypadku podejmowania przez nich pracy (art. 103). Były to wówczas rozwiązania nowatorskie, zwłaszcza, jeśli chodzi o prawa kobiet, dały podstawy do rozwoju różnych form opieki nad rodziną ${ }^{3}$. Narodziła się też wówczas polska szkoła pedagogiki społecznej, zajmująca się

111 listopada to przede wszystkim w $1918 \mathrm{r}$. zaprzestanie działań zbrojnych po podpisaniu rozejmu na froncie zachodnim. W tym dniu w Warszawie tracąca wszelkie znaczenie Rada Regencyjna przekazała Józefowi Piłsudskiemu władzę nad powstającym polskim wojskiem. Pierwsze działania zbrojne na naszych terenach zaczęły się wcześniej, na przełomie października i listopada 1918 r. na południowym wschodzie. Najbardziej znane są walki o Lwów. Ostatnie - to trzecie powstanie śląskie (maj-czerwiec 1921 r.). Zakończenie działań dyplomatycznych w sprawie granic nastąpiło dopiero w marcu $1923 \mathrm{r}$. Są to powszechnie znane ramy chronologiczne, w których zamyka się kształtowanie się granic II Rzeczypospolitej - związane z tym fakty są szeroko omawiane w różnych opracowaniach i podręcznikach, na przykład: C. Brzoza, Wielka historia Polski. Polska w czasach niepodległości i drugiej wojny światowej (1918-1945), vol. 5, Kraków 2003 czy W. Roszkowski, Historia Polski 1914-2005. Nowe uaktualnione wydanie, Warszawa 2006.

${ }^{2}$ Powołuję się tu m.in. na własne badania przedstawione choćby w monografii: Zdrowie i zdrowotność piotrkowian. Z problematyki zdrowotności mieszkańców Piotrkowa Trybunalskiego i powiatu piotrkowskiego na tle całego kraju (od końca lat 20-tych do poczatku 70-tych XX wieku), Wrocław 2006.

3 Konstytucja Rzeczypospolitej Polskiej z 17 marca 1921 r., [w:] J.R. Szaflik (oprac.), Źródła do dziejów Polski w XIX i XX wieku. Lata 1918-1939. Polska Niepodległa, Wybór tekstów źródłowych, vol. 3, Pułtusk 1998, s. 64-86. Teksty dokumentów dot. opieki społecznej oraz zdrowotności wydano drukiem jeszcze przed 1939 r.: S. Grochowski, E. Chwalewnik (oprac.), Opieka społeczna. Zbiór ustaw i rozporzadzeń, Warszawa 1929; K. Prokl, J. Kowalczewski (red.), Polskie prawo sanitarne, zbiór ustaw, instrukcji, okólników i pism okólnych z lat 1918-1935, vol. 1-2, Warszawa 1935-1936. 
badaniami procesów wychowawczo-opiekuńczych, twórczynią jej była Helena Radlińska. Jednym z najważniejszych elementów opieki nad rodziną - podstawową komórką społeczną i najważniejszym środowiskiem wychowawczym - były i są kwestie zdrowotności. Dlatego też warto pod tym kątem prześledzić te sprawy w okresie międzywojennym ${ }^{4}$.

Gdy omawia się problemy zdrowotności i zachorowalności w latach 1918-1939, tak istotne dla prawidłowego funkcjonowania poszczególnych rodzin bez względu na ich podziały, na początku należy przypomnieć, że u progu niepodległości sytuacja w tym zakresie była bardzo zła. A. Chwalba, analizując przedwojenne materiały statystyczne, podał, że ludność Polski, według granic z 1 stycznia 1939 r., zmniejszyła się z ok. $30310000 \mathrm{w}$ dniu 1 stycznia 1914 r. do - w przybliżeniu 26282000 na początku $1919 \mathrm{r}$. W okresie tych ponad czterech lat przyrost naturalny był ujemny, wynosił (w procentach) $-1,2$, o wiele gorzej wyglądał bilans migracyjny: -12,2, a zmiana liczby ludności: $-13,4$. Na polach bitew „wielkiej wojny” poległo, służąc w armiach zaborczych, według różnych danych, od ok. 387 tys. do ponad 450 tys. żołnierzy pochodzących z obszaru późniejszej II Rzeczypospolitej - ojców, synów, braci, dzieci zamieszkujących te ziemie rodzin. Pozostała różnica to $\mathrm{z}$ jednej strony wspomniany minusowy trend migracyjny, głównie przymusowa ewakuacja części ludności z zaboru rosyjskiego w głąb tego państwa w latach 1914-1915. Ważnym czynnikiem było także pogorszenie warunków bytu wszystkich bez wyjątku rodzin. W większości z nich było to przede wszystkim niedożywienie, brak higieny oraz - chyba najtragiczniejsza kwestia - znacznie zwiększona śmiertelność, przeważnie z powodu wielkich epidemii groźnych chorób zakaźnych, dotykająca wszystkich. Te problemy występowały również, często z bardzo dużym nasileniem, wśród polskich rodzin ewakuowanych w latach 1914-1915 w głąb Rosji. Na tym terytorium szczególne spustoszenie powodował dur osutkowy, zwany wówczas powszechnie tyfusem plamistym, szczególnie masowo występujący już w ostatnich latach wielkiej wojny. Wojna domowa, krwawa walka o władzę w tym państwie od końca 1917 r., znacznie pogłębiła ten kryzys ${ }^{5}$.

${ }^{4}$ M. Łobocki, Teoria wychowania w zarysie, Kraków 2009, s. 298-300; W. Okoń, Nowy Stownik Pedagogiczny, wyd. 4, Warszawa 2004, s. 303, 342-343. Ciekawy artykuł opublikowała niedawno J. Majchrzyk-Mikuła: Zdrowie a jakość życia dziecka $w$ domu rodzinnym w okresie międzywojennym, „Wychowanie w Rodzinie” 2016, vol. XIV, nr 2, s. 141-160. Helena Radlińska (1879-1954) - działaczka niepodległościowa, profesor Wolnej Wszechnicy Polskiej, organizatorka Studium Pracy Społeczno-Oświatowej, od 1945 r. profesor Uniwersytetu Łódzkiego. W. Okoń, dz. cyt., s. 342-343.

${ }^{5}$ A. Chwalba, Historia Polski 1795-1918, Kraków 2000, s. 592-594. Odsyłam też do wspomnień i prac wydanych przed wrześniem 1939, na przykład: W. Glinka, Pamiętnik 
Michał Kopczyński, badając wpływ I wojny światowej na poziom życia na terenach byłego Królestwa Polskiego w świetle mierników biologicznych, stwierdził, że został wówczas przerwany „trend sekularny”. Jest to, datujący się od połowy XIX w., a systematycznie opisywany w Rosji od lat 70. XIX w., powolny, ale stały proces wzrostu wysokości ciała ogółu ludności. Można było to obserwować dzięki systematycznym badaniom młodych mężczyzn przez wojskowe komisje poborowe. Gromadzono te informacje głównie dla przygotowania wymiarów mundurów. Stwierdzono, że roczniki poborowych polskiej armii z lat bezpośrednio po 1921 r., których młodzieńczy okres intensywnego wzrostu przypadał na lata 1914-1918, były niższe średnio o od 1,81 do 2,4 cm od swoich nieco starszych rówieśników sprzed konfliktu. Świadczyło to jednoznacznie o trudnych warunkach bytowych ogółu rodzin, przede wszystkim o niedożywieniu. Podobne negatywne różnice, chociaż nie tak duże, występowały też w innych krajach uczestniczących w I wojnie światowej, na przykład we Francji ${ }^{6}$.

W końcowym okresie I wojny światowej największe zagrożenie, na szczęście stosunkowo krótkotrwałe, kilkuletnie, powodowała na całym świecie grypa, zwana popularnie hiszpanką. Dane o ofiarach są jedynie szacunkowe. Gdy mowa o skutkach tej pandemii, należy uwzględnić czas, w jakim się pojawiła - zwłaszcza niedostatek, w jakim żyło wiele rodzin w wyniku długotrwałego konfliktu zbrojnego. Wspomniany A. Chwalba stwierdził, że ,[...] w latach 1918-1921 [...] chorowało około 500 milionów ludzi, a zmarło z jej powodu od 20 do 50, a nawet 100 milionów [...]. Atakowała częściej młodych i silnych niż starych i słabych [...]. Takiej pandemii od czasów «czarnej śmierci», czyli dżumy w XIV wieku, ludzka cywilizacja nie znała"’. Polskie informacje na temat występowania tej choroby na naszych terenach są skąpe. Zarówno w pracach naukowych, jak i na licznych stronach internetowych brak na ten temat konkretnych, szczegółowych, ogól-

z wielkiej wojny, vol. I-IV, Warszawa 1927; S. Wojciechowski, Moje wspomnienia, Warszawa-Lwów 1938 czy W. Grabski, A. Żabko-Potopowicz, Ratownictwo spoteczne w czasie wielkiej wojny (1914-1918), Warszawa 1932, a także współczesnych opracowań, dla przykładu: R. Kołodziejczyk (red.), Społeczeństwo polskie w dobie I wojny światowej $i$ wojny polsko-bolszewickiej 1920 roku, Kielce 2001 czy wspomnianych wcześniej podręczników.

${ }^{6}$ M. Kopczyński, Wpływ I wojny światowej na poziom życia w Królestwie Polskim $w$ świetle mierników biologicznych, „Przegląd Historyczny” 2001, vol. XCII, nr 3, s. 314-315. Według autora było to cofnięcie w czasie o ok. 20-27 lat. Dopiero pod koniec lat 20. nastąpiła istotna poprawa. Można też podać, że np. w latach 1927-1931 średnia wzrostu dla rekrutów z najwyższą kategorią zdrowia A przekraczała nieznacznie $167 \mathrm{~cm}$. Tamże.

${ }^{7}$ A. Chwalba, Samobójstwo Europy. Wielka wojna 1914-1918, Kraków 2014, s. 555-556. 
nopolskich, pełnych danych, zarówno o zachorowaniach, jak i o śmiertelności. Dużo na ten temat pisała jedynie codzienna prasa. Pojawiły się też publikacje kliniczne, ale brak jest spojrzenia obejmującego cały kraj. Spowodowane to było przede wszystkim początkowo wojenną cenzurą państw centralnych, a potem także słabym jeszcze aparatem administracyjnym rodzącego się państwa, zwłaszcza że na wielu obszarach toczyły się działania zbrojne. Można jedynie stwierdzić, że terytorium oraz ludność ziem polskich były jakby nieco na uboczu. Hiszpanka pojawiła się tu stosunkowo późno i - podobnie jak w XIV w. „czarna śmierć” - ta zapewne najgroźniejsza w historii epidemia grypy dokonała u nas stosunkowo niewielkich spustoszeń. Można tak stwierdzić, porównując naszą sytuację w odniesieniu do innych krajów, zarówno w Europie, zwłaszcza zachodniej, jak i na całym świecie, choćby w świetle danych przytaczanych przez A. Chwalbę dotyczących Indii czy Stanów Zjednoczonych Ameryki. Trzeba też jednocześnie podkreślić, że nie popełni się błędu w stwierdzeniu, że ze wszystkich epidemii grypy, które miały miejsce na naszych terenach w XX w., ta przyniosła największą śmiertelnośćc 8 .

$\mathrm{Na}$ ziemiach polskich ok. 100 lat temu niewątpliwie najgroźniejszymi i do tego występującymi z dużym nasileniem przez kilka lat, a w niektórych przypadkach i przez całe dwudziestolecie międzywojenne, były ostre choroby infekcyjne, dziś już w większości nieznane na naszym terenie. Można zaliczyć do nich przede wszystkim dury, głównie: brzuszny i osutkowy - tyfus plamisty, ospę prawdziwą, czerwonkę, płonicę, błonicę, a nawet zimnicę - inaczej malarię i cholere azjatycką. Obserwowano też wówczas dużą zapadalność na choroby określane jako społeczne: gruźlicę i schorzenia weneryczne.

U progu niepodległości dane epidemiologiczne dotyczące większości ostrych chorób infekcyjnych były bardzo niepokojące i złe. W 1919 r. na dury: osutkowy, brzuszny i powrotny oraz na cztery inne choroby: cholerę, ospę prawdziwą, czerwonkę, a także na zimnicę zapadło, według niepełnych danych dotyczących tylko ziem będących wówczas w jurysdykcji polskiego rządu (a więc bez Pomorza Gdańskiego, części obszarów wschodnich oraz Górnego Śląska) łącznie 464644 osób, z czego zmarło 22 975. Od tego czasu zachorowalność

${ }^{8}$ Tamże. Autor nie wspomina o skali strat na naszych ziemiach. Kilka lat temu artykuł na ten temat opublikował J. Wnęk: Pandemia grypy hiszpanki (1918-1919) w świetle polskiej prasy, „Archiwum Historii i Filozofii Medycyny” 2014, vol. 77, s. 16-23. Również i ww. nie dysponował pełnymi danymi, ograniczając się głównie do źródeł $\mathrm{z}$ ówczesnej prasy. Wszystkich zainteresowanych odsyłam też do Internetu, gdzie pod hasłem grypa hiszpanka zamieszczono szereg interesujących materiałów. 
spadała, początkowo nieznacznie - do 415597 chorych w roku następnym (na bardzo zmieniającym się obszarze) - przy zwiększonej liczbie zgonów - 30 893. Znaczącą poprawę odnotowano w roku 1921 w ostatnim, gdy toczyły się walki o kształt Rzeczypospolitej. Zachorowało wtedy na wspomniane choroby już tylko (czy jednak aż) 184463 osób, nie udało się wyleczyć 12 853. Ogółem w latach 1919-1926 te siedem schorzeń na obszarze Rzeczypospolitej wykryto u co najmniej 1329254 pacjentów, z czego zmarło 86100 osób. Z wymienionych niewątpliwie najbardziej rozpowszechniony był dur osutkowy - tyfus plamisty. Roznoszony przez wszy, przy braku higieny, z łatwościa atakował całe rodziny. W latach 1919-1920 w polskich statystykach odnotowano nie mniej niż 770000 zachorowań i ponad 41000 zgonów na tę chorobę. Spadek nastąpił w roku następnym - niecałe 50000 zachorowań, z czego zmarło niewiele ponad 4000 chorych. Echa tych wydarzeń dotarły nawet do Nowego Jorku. Tamtejsza prasa opisywała tę epidemię, ostrzegając mieszkańców miasta przed emigrantami ze środkowej i wschodniej Europy, którzy mogli przenieść ją do Ameryki. Rzeczywiście takie przypadki miały wówczas miejsce. Niezwykle groźna była też ospa prawdziwa z powodu bardzo dużej śmiertelności. W okresie 1919-1921 stwierdzono ponad 13000 przypadków i aż ponad 2000 zgonów. Spustoszenie czyniła też czerwonka. W trzech pierwszych latach niepodległości zapadło na nią ponad 80000 osób, a zmarło prawie 12000 . Groźne były też choroby społeczne, a zwłaszcza nieuleczalna wówczas przy ostrym przebiegu gruźlica. Dane na ten temat są niepełne. Wiadomo, że z powodu tej ostatniej choroby w roku 1919 na każde 10000 mieszkańców w stolicy zmarło ponad 59 osób, we Lwowie blisko 76, w Poznaniu nieco ponad 43, a w Krakowie prawie 48 obywateli. Choroba ta była bardzo niebezpieczna dla ubogich rodzin z powodu niemożności izolacji chorego, a także braku środków na długotrwałe leczenie, lepsze wyżywienie czy ewentualną utratę pracy. Dla przykładu w powiatowym mieście - Piotrkowie Trybunalskim - nawet pod koniec okresu międzywojennego, w 1938 r., lokale jednoizbowe stanowiły ok. $40 \%$ wszystkich mieszkań, a zamieszkiwała w nich ponad 1/3 mieszkańców trybunalskiego grodu. Można dodać, że w co piątym z nich gnieździło się sześć lub więcej osób, czyli w przybliżeniu cała ówczesna niezamożna rodzina wielopokoleniowa. Tyle samo mieszkańców dysponowało mieszkaniami dwupokojowymi. Gdy więc w takich rodzinach ktoś zachorował na gruźlicę czy jakąś chorobę infekcyjną o ostrym przebiegu, łatwo zapadali na nią wszyscy współmieszkańcy, nie było jakiejkolwiek możliwości izolacji 
chorego. Podobnie, a nawet gorzej było w rodzinach chłopów, gdzie warunki lokalowe były jeszcze trudniejsze. Normą było tam łączenie niewielkich mieszkań z pomieszczeniami dla zwierząt, jak również, zwłaszcza w okresie zimy, wpuszczanie do domów, głównie do kuchni, drobiu. Trudno też tam mówić o zachowaniu jakiejkolwiek higieny ${ }^{9}$.

Wymienione choroby miały różną etiologię, ale w większości wypadków wspólnym mianownikiem był brak higieny i nieprzestrzeganie podstawowych przepisów sanitarnych. Przytaczane w literaturze dane epidemiologiczne dotyczące większości wymienionych powyżej chorób, odnoszące się zwłaszcza w naszym kraju do okresu walk o niepodległość i granice, potwierdzają wszystkie dotychczasowe teorie dotyczące ich etiologii. Wraz z rozwojem w XIX w. mikrobiologii i epidemiologii popularnym poglądem było stwierdzenie, że główną przyczyną zapadalności były drobnoustroje, które wówczas stopniowo poznawano i opisywano. Potem pojawiło się dodatkowo pojęcie triady epidemiologicznej, czyli: występuje odpowiedni czynnik chorobotwórczy, który znajduje sprzyjające środowisko - fizyczne, biologiczne i społeczne, co prowadzi do osoby, która ma podatne cechy biologiczne, społeczne oraz zachowania sprzyjające zapadalności na daną chorobę. Rozwinięciem tych poglądów było stwierdzenie, że do wzrostu

\footnotetext{
${ }^{9} \mathrm{Na}$ ten temat literatura jest bogata. Wykorzystałem: urzędowe zestawienie opublikowane tuż przed II wojną światową - Dwadzieścia lat publicznej stużby zdrowia w Polsce odrodzonej 1918-1938, wprowadzenie E. Piestrzyński, Warszawa 1939, s. 43-68; A. Felchner, Zdrowie i zdrowotność piotrkowian. Z problematyki zdrowotności mieszkańców Piotrkowa Trybunalskiego i powiatu piotrkowskiego na tle całego kraju (od końca lat 20-tych do początków 70-tych XX wieku), Wrocław 2006, s. 34-40, 97-112; E. Więckowska, Walka $z$ ostrymi chorobami zakaźnymi w Polsce w latach 1918-1924, Wrocław 1999, s. 217-240. Trudne warunki bytowe mieszkańców województwa lubelskiego oraz zagrożenia zdrowotne przedstawiła też J. Majchrzyk-Mikuła, Higiena szkolna na Lubelszczyźnie w latach 1918-1939 na tle całego kraju, Piotrków Trybunalski 2013, s. 48-105, a o sytuacji w Nowym Jorku pisała S. Kuźma-Markowska, Zaraza u bram Nowego Jorku: reakcja amerykańskiej opinii publicznej na epidemię tyfusu w Polsce po I wojnie światowej, „Medycyna Nowożytna. Studia nad Kulturą Medyczną” 2014, vol. 20, z. 1, s. 61-85. Można dodać, że M. Ciesielska w opracowaniu Tyfus groźny zabójca i cichy sprzymierzeniec, Warszawa 2015, przypomniała tzw. Listę Marcina Kacprzaka, opublikowaną w 1928 r. i zawierającą nazwiska 314 polskich lekarzy zmarłych tylko na dur osutkowy w latach 1914-1928. Najwięcej, bo ponad $220 \mathrm{z}$ nich odeszło w latach 1918-1921. Z wymienionych ponad 150 pracowało w cywilnej służbie zdrowia, a pozostali to lekarze związani $\mathrm{z}$ wojskiem lub pracownicy specjalnych instytucji przeciwepidemicznych. Tamże, s. 30-38. Należy też dla porównania dodać, że w 1921 r. w całej Polsce było zaledwie ok. 5,5 tys. lekarzy, w 1926 r. w całym województwie warszawskim (bez stolicy) pracowało ich 314, a w krakowskim (bez Krakowa) 335, można więc powiedzieć, że z powodu tej choroby straciło życie tylu lekarzy, ilu pracowało wówczas w dużym województwie. E. Więckowska, Lekarze, jako grupa zawodowa w II Rzeczypospolitej, Wrocław 2004, s. 37-40.
} 
zachorowalności przyczynia się wiele różnych czynników tworzących całą sieć epidemiologiczną, uwzględniających też: podatność, kwestie społeczno-środowiskowe oraz warunki ekonomiczno-polityczne. $\mathrm{W}$ ostatnich kilkunastu latach dodano jeszcze czynnik genetyczny ${ }^{10}$.

Gdy mowa o genezie tak niekorzystnych zjawisk w dziedzinie zdrowotności dla ogółu rodzin z obszaru II Rzeczypospolitej w pierwszych latach niepodległości, należy oczywiście uwzględnić fakt olbrzymich zniszczeń wojennych, brak na przeważającym obszarze podstawowych urządzeń higienicznych oraz nikłą świadomość prozdrowotną ogółu społeczeństwa, na co duży wpływ miał niski poziom wykształcenia. Istotne było wielkie wojenne zubożenie $\mathrm{i}$ tak w większości biednych rodzin. Ważną rolę odgrywał w związku z tym ogólny niedostatek, niedożywienie, stres spowodowane długotrwałymi wydarzeniami wojennymi, a w wypadku chorób wenerycznych typowe dla długotrwałych konfliktów zbrojnych obniżenie standardów moralnych. Jeszcze dziesięć lat po wojnie - w 1931 r. - jakiekolwiek „wygody” posiadało w całym kraju zaledwie niespełna $43 \%$ budynków miejskich, z czego kanalizacje prawie $13 \%$, wodociągi niemal 16\%, elektryczność niepełne $38 \%$, a gaz zaledwie $7,5 \%$. Najlepiej było na zachodzie kraju, najgorzej na terenach wschodnich. W statystykach brak na ten temat danych o przeważających w Polsce terenach wiejskich, gdzie te podstawowe instalacje cywilizacyjne były prawie zupełnie nieznane, zwłaszcza w rodzinach chłopskich. Inna sytuacja mogła jedynie panować w rodzinach ziemiańskich, w zabudowaniach dworskich, zwłaszcza, jeśli w skład kompleksu wchodziły zakłady przetwórstwa rolnego (np. gorzelnie czy cukrownie). Złą sytuację pogłębiał też dodatkowo niski poziom wykształcenia społeczeństwa, zwłaszcza na terenach wiejskich oraz dawnego zaboru rosyjskiego. Analfabetami w $1921 \mathrm{r}$. była niemal $1 / 3$ populacji $\mathrm{w}$ wieku $30-39$ lat i niespełna $55 \%$ osób mających 60 i więcej lat. Najwięcej było ich na wsi, gdzie odsetek najstarszych osób niepotrafiących czytać i pisać zbliżał się do $60 \%$. Mimo rozwoju szkolnictwa, obowiązku i przymusu szkolnego nawet jeszcze w połowie okresu międzywojennego - w 1931 r. - widać było w tym względzie jeszcze wyraźnie podział na zabory: w Katowicach czy w Poznaniu analfabetów prawie nie było, za to w samej stolicy było ich prawie 100000 , podobnie - procentowo - w Wilnie. Taki poziom wykształcenia, a co za tym idzie - nieznajomość podstawowych

${ }^{10}$ Oczywiście te teoretyczne rozważania przedstawiono $\mathrm{z}$ konieczności $\mathrm{w}$ bardzo dużym skrócie. Wszystkich zainteresowanych odsyłam do stron internetowych, do tekstu Determinanty chorób $i$ zdrowia - PZWL, www.wydawnictwopzwl.pl/download/229360100.pdf [dostęp: 16.07.2018]. 
zasad higieny, niemożliwość dotarcia do takich rodzin z jakakolwiek informacją na piśmie, nawet z najprostszą ulotką - powodował niezrozumienie najbardziej prostych spraw. Można to zilustrować przykładami z okolic Piotrkowa Trybunalskiego. Jak donosiła ówczesna lokalna prasa, w grudniu 1919 r. mieszkańcy jednej z podpiotrkowskich wiosek protestowali przeciwko działaniom lekarza, który zarządził kąpiel i ewentualne odwszenie $\mathrm{w}$ związku $\mathrm{z}$ epidemią duru osutkowego. „Nakazaną kąpiel uznano za szykanę, chciano zlinczować miejscowego aptekarza, podejrzewając go o współdziałanie w urządzeniu domu izolacyjnego [...], który uznano za «pański wymysł» i «szlachecką podrywką». Kiedy lekarz nakazał kąpiel, obywatele [...] jednogłośnie założyli swoje veto oświadczając: «My ta [...] nie potrzebujemy kąpieli. My starsi ludzie i takie figle już nas się nie trzymają». Rada gminy wysłała ostry protest do Ministerstwa Spraw Wewnętrznych przeciw zarządzeniu kąpieli" ${ }^{11}$. Te przykładowe dane dotyczące sytuacji w całym kraju, w różnych obszarach, dobrze ilustrują niektóre $\mathrm{z}$ wymienionych przyczyn, pokazują też bardzo złe warunki bytu większości rodzin, szczególnie na wsi, i w większości tego środowiska brak zachowań prozdrowotnych ${ }^{12}$.

Podczas analizy powyższego materiału należy jeszcze raz podkreślić, że stan zdrowotny zdecydowanej większości polskich rodzin w pierwszych latach niepodległości był na ogół bardzo niepokojący. Obok wielu różnych innych zagrożeń i trudności te związane ze zdrowiem dotykały wszystkich polskich rodzin, ale różna była możliwość zwalczania czy ograniczania skutków epidemii, a także najgroźniejszych chorób społecznych. W najlepszej sytuacji były zamożne rodziny wielkomiejskie, w najgorszej ubogie wiejskie, zamieszkujące

${ }^{11}$ „Dziennik Narodowy”, niedziela, 7.12.1919 r., nr 197/V; cytat ten znajduje się też w moim artykule: $Z$ problematyki zwalczania chorób zakaźnych $w$ Piotrkowie i powiecie piotrkowskim w latach 1919-1921 - zagadnienia medyczne i społeczne, [w:] B. Płonka-Syroka (red.), Choroba, jako zjawisko społeczne i historyczne. Studia z Dziejów Kultury Medycznej, Wrocław 2001, s. 219. Zamieściłem tam też zbliżone przykłady reakcji ówczesnego społeczeństwa na podobne działania, mające przecież na celu zwalczanie szerzącej się epidemii duru osutkowego - jak wiadomo roznoszonego przez wszy. W niektórych innych miejscowościach tego powiatu mieszkańców często doprowadzano do łaźni $\mathrm{w}$ asyście policji. $\mathrm{W}$ dniach przeznaczonych na kąpiel dla kobiet przedstawiciele specjalnych Gminnych Komisji Sanitarnych zastawali przeważnie tylko mężczyzn i na odwrót. Starosta powiatowy musiał też wydać w 1920 r. specjalny okólnik dla służby folwarcznej polecający, aby przed Wielkanocą wybielono ściany mieszkań, a całe rodziny wykąpały się, wyczyściły i zmieniły słomę w siennikach. Tamże, s. 212-220. Podobne przykłady podaje też $\mathrm{z}$ terenu Lubelszczyzny J. Majchrzyk-Mikuła we wspomnianej pracy o higienie szkolnej.

12 Dwadzieścia lat publicznej, dz. cyt., s. 48; Mały Rocznik Statystyczny Polski wrzesień 1939 - czerwiec 1941, Londyn 1941, s. 17, 29. 
odległe od większych skupisk przysiółki na wschodzie Rzeczypospolitej. Obok czynników ekonomicznych, zamożności czy biedy ważną rolę odgrywał tam niezwykle utrudniony dostęp do fachowej pomocy medycznej, liczony nieraz w dziesiątkach kilometrów polnych dróg, szczególnie w pierwszych latach niepodległości, gdy lekarzy było bardzo mało. Według materiałów Naczelnej Izby Lekarskiej z 1926/1927 r. w województwie nowogródzkim pracowało zaledwie 89 lekarzy, z czego $11 \mathrm{w}$ Nowogródku, w województwie wileńskim odpowiednio 348, w tym w większości w uniwersyteckim Wilnie - 292, a w województwie poleskim było ogółem 113 lekarzy, z czego 26 w Brześciu nad Bugiem. Można też dodać, że w miastach powiatowych i miasteczkach na tych terenach było przynajmniej po kilku-kilkunastu lekarzy, w tym w stacjonujących tam licznych jednostkach wojskowych. W takiej sytuacji, odliczając lekarzy zamieszkujących tereny zurbanizowane, można stwierdzić, że faktycznie na wsiach nie było ich prawie wcale. Należy więc stwierdzić, biorąc pod uwagę dodatkowo fakt, że na tych obszarach zdecydowanie przeważała ludność wiejska, iż większość rodzin tam zamieszkujących była w pierwszych latach niepodległości faktycznie pozbawiona dostępu do lekarzy ${ }^{13}$.

W okresie dwudziestolecia międzywojennego sytuacja rodzin w obszarze zdrowotności czy zachorowalności uległa w wielu przypadkach poprawie. Jedną z takich istotnych dla ogółu rodzin zmian wpływających na zmniejszenie zagrożeń w obszarze zdrowotności było zwiększenie dostępności do lekarzy, ich liczba bowiem stale rosła. W związku z rozwojem wyższego szkolnictwa medycznego zwiększyła się ich liczebność do prawie 13000 - a więc podwoiła się w stosunku do stanu z początku lat 20. Dalej jednak utrzymywały się rażące dysproporcje $\mathrm{w}$ ich rozmieszczeniu, a i sama liczebność pod koniec lat 30. mimo wszystko, w porównaniu z większością krajów europejskich, nie była imponująca. Najwięcej w dalszym ciągu lekarzy było w dużych miastach, zwłaszcza uniwersyteckich, najmniej na terenach wiejskich, we wschodnich województwach. Oficjalne dane pokazują, jak te różnice zmieniały się, ale ten trend był bardzo powolny. Liczba lekarzy we

${ }^{13}$ E. Więckowska, Lekarze, jako grupa..., dz. cyt., s. 39-41. Brak lekarzy na wsi był problemem ogólnopolskim, ale szczególnie dotkliwym na obszarach wschodnich, będących wcześniej pod zaborem rosyjskim. Obszary te były bowiem bardzo słabo zurbanizowane, jednocześnie o wątłej sieci połączeń drogowych czy kolejowych. Mały Rocznik..., dz. cyt., s. 16-17, 86. Na temat walki z chorobami na wsi, gdzie rodziny często zdane były na miejscowych znachorów, ciekawie pisała też H. Kulik, Stan zdrowia i lecznictwo wsi polskiej w okresie XX międzywojennego, [w:] R. Meissner (red.), Medycyna i farmacja w XIX i XX wieku, Poznań 2007, s. 249-254. 
wschodnich województwach wrosła z ok. 700 w 1921 r. do ponad 1300 w 1935 r., ale podobnie na przykład w samej stolicy - odpowiednio z ponad 1300 do ok. 2850. Średnio na terenach wschodnich na jednego lekarza przypadało $\mathrm{w}$ połowie lat 30 . ok. 4400 potencjalnych pacjentów, a na pozostałych obszarach - w przybliżeniu 2500. Sytuacja rodzin zamieszkujących wiejskie tereny Wileńszczyzny czy Polesia w dalszym ciągu nie była zatem pod tym względem najlepsza ${ }^{14}$.

Poza stosunkowo dużymi, pozytywnymi zmianami kadrowym może nawet ważniejszą kwestią dla rodzin, zwłaszcza wiejskich, był rozwój ośrodków zdrowia. Dzisiaj taka placówka kojarzy się przede wszystkim z lecznicą, posiadającą szereg gabinetów specjalistycznych, nieraz z laboratoriami oraz pracowniami. Najnowsze, dysponujące odpowiednimi funduszami mają też bogate, nowoczesne wyposażenie diagnostyczne. Ośrodki zdrowia, które zaczęto tworzyć w Polsce od 1925 r., prowadziły przede wszystkim działalność profilaktyczną. Leczeniem zajmowały się $\mathrm{w}$ nich tylko specjalistyczne przychodnie chorób społecznych, głównie przeciwgruźlicze, przeciwjaglicze oraz przeciwweneryczne. Ośrodki działały kompleksowo, roztaczając opiekę nad kobietą ciężarną, niemowlęciem, przedszkolakiem, uczniem oraz w zakresie wspomnianych chorób społecznych. Stopniowo powstawały też i inne przychodnie, na przykład przeciwalkoholowe. Docelowo przewidywano utworzenie ok. 1000 takich ośrodków zdrowia - po kilka w każdym powiecie. Centralny, największy dla danego obszaru, mieścił się w stolicy powiatu, a cały teren każdej z tych jed-

${ }^{14}$ E. Więckowska, Lekarze, jako grupa..., dz. cyt., s. 37-61 - zamieszczono tam szereg tabel i różnych porównań. Odsyłam też do wykorzystywanego już opracowania Dwadzieścia lat publicznej..., dz. cyt., s. 29-33. Wzrost liczby lekarzy widać też na innych przykładach. W Piotrkowie Trybunalskim, jednym z największych miast województwa łódzkiego, w 1922 r. pracowało tylko 21 lekarzy, a na terenie powiatu zaledwie czterech - dwóch w niewielkim wówczas Bełchatowie oraz po jednym w jeszcze nieco mniejszym Sulejowie i na terenie dużej wsi czy raczej osady - w Kamieńsku. Byli to sami mężczyźni. Pod koniec dwudziestolecia międzywojennego - w 1937 r. - było ich już ogółem 50, z czego 12 na terenie powiatu: $5 \mathrm{w}$ Bełchatowie, $2 \mathrm{w}$ Sulejowie oraz po $1 \mathrm{w}$ dużych wsiach - osadach: w Gorzkowicach, Kamieńsku, Moszczenicy, Wolborzu i Woli Krzysztoporskiej. Zawód ten przestał być też w tym mieście domeną mężczyzn, wśród wymienionych były już 4 lekarki, absolwentki polskich uniwersytetów. Silniej sfeminizowani byli stomatolodzy, których liczba też rosła. W 1930 r. na tym terenie pracowało ich 15, w tym 8 kobiet, a w 1937 r. - 17. Należy też dodać, że w II RP tuż przed wybuchem wojny, w 1938 r., wśród lekarzy było już 15,7\% kobiet. Archiwum Państwowe w Piotrkowie Trybunalskim (APPT), Starostwo Powiatowe Piotrkowskie 1919-1939, t. 2260, sprawozdanie z 1937 r.; Dziennik Urzędowy Województwa Łódzkiego, 1922 r., nr 32, s. 954; A. Felchner, Zdrowie i zdrowotność..., dz. cyt., s. 220-224; H. Kulik, Feminizacja zawodu lekarza $w$ Polsce, [w:] R. Meissner (red.), Medycyna i farmacja XIX i XX wieku, Poznań 2007, s. 243-245. 
nostek administracyjnych zaczęto dzielić na rejony, obejmujące kilka okolicznych gmin - w każdym z nich tworzono odrębny, nieco mniejszy ośrodek zdrowia. W powiatowym starano się zorganizować wszystkie przychodnie i pracownie, a w rejonowych tylko najpotrzebniejsze na danym terenie. Trzeba dodać, że placówki te stanowiły jednak znaczne obciążenie finansowe miejscowych samorządów, które pokrywały ok. 3/4 kosztów całkowitego utrzymania, dlatego też ich organizacja została rozłożona $\mathrm{w}$ czasie. O pewnym dynamizmie rozwoju takich instytucji świadczy jednak $\mathrm{z}$ drugiej strony fakt systematycznego wzrostu liczebności zarówno samych ośrodków, jak i znajdujących się w nich działów. Pewne zahamowanie nastąpiło jedynie w latach wielkiego kryzysu w pierwszej połowie lat 30 . XX w. Po 10 latach od momentu powstania dwóch pierwszych - w roku 1934 - działało w całej Rzeczypospolitej już 260 ośrodków zdrowia, w 1937 r. - 482, a przed wybuchem II wojny światowej przekroczono granicę 600 placówek. Najwięcej było w nich przychodni przeciwgruźliczych - w 1934 r. 246, a trzy lata później już 436. Nieco mniej zorganizowano gabinetów do walki z jaglicą, odpowiednio 231 i 444, a najmniej dla chorych wenerycznie - 119 w 1934 r. i 314 w 1937 r. Bardzo ważne dla rodzin były przychodnie profilaktyczne. Najwięcej działało gabinetów zajmujących się opieką nad dzieckiem - w 1934 r. 170, a w 1937 r. - 364. Opiekę nad matką roztaczało odpowiednio 119, a trzy lata później już 222 gabinetów, systematycznie i jeszcze bardziej wzrastała też liczba komórek zajmujących się higieną i profilaktyką szkolną - z 112 do 322 na dwa lata przed wybuchem wojny. Aby ułatwić dokształcanie i szkolenie wszystkich pracowników tych placówek, zaczęto organizować wzorcowe wojewódzkie ośrodki zdrowia. W połowie lat 30. istniały one już nie tylko w stolicy, ale przede wszystkim na „ścianie wschodniej”, czyli na obszarach najbardziej zagrożonych pod względem epidemiologicznym - w Brześciu, we Lwowie, w Stanisławowie, Tarnopolu i Wilnie. Rozpoczęto też wówczas organizację kolejnych takich wojewódzkich centrów zdrowia - w Lublinie i Poznaniu. Kilkutygodniowe kursy dla lekarzy z takich placówek organizował też Państwowy Zakład Higieny. Takie dodatkowe pogłębianie wiedzy było konieczne z powodu stale zwiększającej się liczby personelu, zapewne nie zawsze odpowiednio przygotowanego do takiej pracy. Wymagała ona nie tylko głębokiej wiedzy medycznej, gdyż często lekarz czy pielęgniarka działali samotnie na rozległym wiejskim terenie swojego rejonu, ale także umiejętności prowadzenia np. prelekcji z dziedziny profilaktyki zdrowia dla osób z minimalnym wykształceniem, 
nastawionych nieufnie, jak zilustrował to przytoczony wcześniej cytat z piotrkowskiej gazety z 1919 r. W latach 1934-1937 liczba lekarzy ośrodków zdrowia wzrosła z 662 do 1138, pielęgniarek z 453 do 840, a kontrolerów sanitarnych z 65 do 115 . Zwiększała się też liczba osób znajdujących się pod opieką tych placówek. Według oficjalnych danych w 1934 r. w całym kraju zarejestrowanych w różnych ośrodkach było prawie 524000 osób, a trzy lata później już ponad 1400000 . Trudno tutaj policzyć, ile było rodzin korzystających z pomocy takich placówek. W wypadku gabinetów dla kobiet można przypuszczać, że matka i ewentualnie najstarsze córki, w przypadku przychodni przeciwgruźliczej - cała rodzina była zapisywana i umieszczana pod nadzorem specjalistów, a przy stwierdzeniu choroby wenerycznej - zapewne robiono wywiad środowiskowy. Można jednak bez popełnienia większego błędu stwierdzić, że taki ośrodek był jedyną instytucją medyczną dostępną dla rodzin z najuboższych warstw ludności miejskiej oraz dla większości osób zamieszkujących wsie i małe miasteczka. W latach 30. stawał się też najważniejszą placówką zajmującą się systematycznie opieką medyczną nad uczniami ${ }^{15}$.

W niewielkim objętościowo tekście nie sposób przedstawić wszystkie zmiany, które zaszły w dziedzinie zdrowotności i zachorowalności w okresie dwudziestolecia międzywojennego, zwiększenia lub zmniejszenia zagrożeń dla polskich rodzin $\mathrm{w}$ tym ważnym obszarze życia społecznego. Można jedynie na niektórych przykładach pokazać najważniejsze kierunki przemian.

Do chorób, których występowanie niemal zupełnie albo w bardzo dużym stopniu ograniczono na przestrzeni omawianego okresu, należały niewątpliwie trzy: cholera, ospa i dur osutkowy. Pierwsza z nich pojawiała się tylko incydentalnie w okresie walk, głównie na wschodzie, stosowano wtedy masowe szczepienia - w sumie $\mathrm{w}$ ten sposób zabezpieczono ponad 2000000 osób - i od 1923 r. już nie notowano zachorowań. Inaczej było w wypadku ospy prawdziwej (naturalnej). Była ona dla rodzin jedną z najgroźniejszych ostrych chorób infekcyjnych, głównie ze względu na dużą śmiertelność i łatwość zarażenia. Stosunkowo szybko jednak poradzono sobie z tym zagrożeniem. Ostatnie masowe zachorowania - 821 przypadków, 126 zgonów, zanotowano w $1924 \mathrm{r}$. W latach 30. wykrywano tylko pojedyncze przypadki zachorowań i zgonów. Na niektórych terenach tej choroby w ogóle nie

${ }^{15}$ Dwadzieścia lat publicznej..., dz. cyt., s. 22-27; A. Felchner, Zdrowie i zdrowotność..., dz. cyt., s. 251-256; J Majchrzyk-Mikuła, Higiena szkolna..., dz. cyt., s. 304-308; Sprawozdanie o stanie zdrowotnym Rzeczypospolitej Polskiej oraz o działalności władz i instytucji zdrowia publicznego w latach 1932-1933, Warszawa 1935, s. 57-58. 
stwierdzano (np. Lubelszczyzna czy Piotrków Trybunalski i powiat piotrkowski). Nastąpiło to głównie z powodu wprowadzenia specjalną ustawą sejmową już 19 lipca 1919 r. obowiązku przymusowych szczepień przeciwospowych. W pierwszych latach niepodległości, z powodu ciągłych migracji i przemieszczeń ludności, zwłaszcza powrotu wielu rodzin z Rosji, gdzie nie było takiego obowiązku, choroba ta występowała, jak wspomniano, dość często. O skali szczepień świadczą choćby przykładowe dane: w 1924 r. zaszczepiono ponad 1600000 dzieci, a w 1933 r. - ponad 2200 000. Była to właściwie jedyna skuteczna metoda walki z tą groźną chorobą, co doprowadziło w końcu lat 70. $\mathrm{XX}$ w. do zupełnego wyeliminowania ospy na całym świecie. W okresie międzywojennym w wypadku pojawienia się tej choroby lekarz powiatowy zarządzał tzw. szczepienia z konieczności, które obejmowały całe otoczenie pacjenta, czasami nawet wszystkich mieszkańców okolicznych domów, wsi czy gminy. Przeprowadzano je na koszt państwa. Szczepienia zapobiegawcze, rutynowe, organizował i finansował lokalny samorząd ${ }^{16}$.

Inaczej kształtowała się sytuacja w wypadku ostatniej z wymienionych chorób. Masowo występujący w początkach II Rzeczypospolitej dur plamisty również przestał zagrażać na tak dużą skalę. Nastąpiło to głównie dzięki licznym działaniom profilaktycznym. Między innymi sprawdzano czystość i walczono z wszawicą, w tym szczególnie w placówkach oświatowych. Kontrolowane były też rodziny i mieszkania uczniów, u których stwierdzono zaniedbania higieniczne. Nie zawsze podstawowe wymogi czystości były przestrzegane nawet w rodzinach, które starały się o jak najwyższe wykształcenie swoich dzieci. Według oficjalnych danych statystycznych wszawicę w roku szkolnym 1922/1923 stwierdzono u 3239 uczniów elitarnych w II Rzeczypospolitej szkół średnich (2,94\% ogółu zbadanych), w roku następnym - u 3746 (2,79\%), a w 1925/1926 r. wszawicę miało 2815 uczniów szkół średnich $(2,2 \%)$ oraz 549 słuchaczy seminariów nauczycielskich

${ }^{16}$ O skuteczności szczepień świadczą też dane z okresu tuż przed wybuchem I wojny światowej. Na terenie zaboru niemieckiego (dawniej pruskiego), gdzie obowiązek szczepień był bardzo skrupulatnie egzekwowany, ospy praktycznie nie było, w Galicji wykrywano ok. 30 przypadków, a na terenie tylko byłego Królestwa Polskiego - kilka tysięcy rocznie. Dwadzieścia lat publicznej..., dz. cyt., s. 48-49; A. Felchner, Zdrowie i zdrowotność..., dz. cyt., s. 122-125, 297-298; J. Majchrzyk-Mikuła, Higiena szkolna..., dz. cyt., s. 89-91; Sprawozdanie o stanie zdrowotnym..., dz. cyt., s. 20-21. Ciekawe informacje na temat ospy prawdziwej znajdują się też w publikacji: B. Różańska-Gambal, Występowanie epidemii ospy prawdziwej na świecie od czasów starożytnych po wspótczesne, „Medycyna Nowożytna. Studia nad Kulturą Medyczną” 2008, vol. 15, z. 1-2, s. 31-59 oraz w Internecie, jeśli tylko wpisze się interesujące nas hasło. 
$(2,39 \%)$. Widać tutaj powolny postęp, ale skoro nawet wśród młodzieży mającej duże aspiracje, $\mathrm{w}$ większości zapewne pochodzącej $\mathrm{z}$ rodzin o wyższym statusie społecznym, występowały takie zaniedbania, to trudno wymagać, by różne przepisy sanitarne były przestrzegane na biednej wsi czy w najuboższych, najmniej wykształconych kręgach ludności miejskiej. Mimo masowych działań profilaktycznych zachorowalność na dur osutkowy w latach 30. ubiegłego wieku utrzymywała się na mało zmiennym poziomie - od niemal 2000 do ponad 5000 osób w skali całego kraju. Śmiertelność była też spora - od ponad 100 do 300 zgonów rocznie. W mniejszym wymiarze, na przykład na Lubelszczyźnie, według ogólnopolskich danych w roku 1932 było 140 przypadków przy 6 zgonach, a dwa lata później już 268 zachorowań i 18 zgonów. Mimo tego występowanie tej choroby, jak widać, zostało znacznie ograniczone i jej zagrożenie dla rodzin wyraźnie zmalało. Stosowano też $\mathrm{w}$ razie potrzeby szczepionki wprowadzone przez lwowskiego profesora R. Weigla ${ }^{17}$, ale z powodu dość dużych kosztów nie były one masowe - rocznie szczepiono kilka tysięcy osób ${ }^{18}$.

Istniała też grupa ostrych chorób infekcyjnych, których występowania nie udało się w okresie międzywojennym ograniczyć. Należał do nich na przykład dur brzuszny. Jego endemiczne występowanie związane było również z brakiem higieny, w tym wypadku używania zakażonej wody, głównie z niedbale wykonanych studzien. Każdego roku w skali całego kraju notowano kilkanaście tysięcy przypadków zachorowań - od ponad 11-12 000 na początku lat 30. do ponad 19-20 000 w roku 1927 i 1932 przy ponad 1000 zgonów w latach najbardziej obfitujących w zachorowania. Były więc naprzemiennie lata, gdy ta choroba występowała ze stosunkowo małym nasileniem, by już w następnym roku wybuchnąć ze zdwojoną siłą. Te liczby wskazują również, jak duże zagrożenie stanowiła ta choroba. W wypadku jej wystąpienia zapadały na nią całe rodziny, które korzystały z zanieczyszczonej wody ${ }^{19}$. Charakterystyczne opisy znajdują się w oficjalnym sprawoz-

\footnotetext{
${ }_{17}$ Ostatnio ukazała się ciekawa biografia tego wybitnego uczonego: M. Urbanek, Profesor Weigl i karmiciele wszy, Warszawa 2018.

${ }_{18}$ Dwadzieścia lat publicznej..., dz. cyt., s. 48-50; J. Majchrzyk-Mikuła, Higiena szkolna..., dz. cyt., s. 89-91; „Rocznik Statystyki Rzeczypospolitej Polskiej” 1928, vol. VI, s. 468; Sprawozdanie o stanie zdrowotnym..., dz. cyt., s. 21-22. Można dodać, że w materiałach archiwalnych są czasami różne sprzeczne dane, ale mimo to widać wyraźnie, niewielkie oczywiście w stosunku do pierwszych lat niepodległości, stałe zagrożenie ze strony tej choroby. Stąd na przykład, jak świadczą źródła ikonograficzne, wielu ówczesnych uczniów czy też żołnierzy było bardzo krótko ostrzyżonych. Powód był jeden - zagrożenie wszawicą.

${ }^{19}$ Dwadzieścia lat publicznej..., dz. cyt., s. 48-59.
} 
daniu. W czerwcu 1933 r. wybuchła lokalna epidemia w Tychach na Śląsku. Początkowo stwierdzono 15 zachorowań, a w kolejnych tygodniach następne. „Wybuch epidemii spowodowany był prawdopodobnie przez spożycie wyrobów mięsnych ze sklepu rzeźnika [...]. Woda z podejrzanych studzien wysłana została do zakładu badania żywności w Katowicach. Analiza wykazała wysoce zanieczyszczoną wodę w studniach w domu, gdzie mieścił się podejrzany sklep" ${ }^{20}$. Inny przypadek miał miejsce w miasteczku Skarszewy koło Kościerzyny na Pomorzu. W ciągu kilku tygodni sierpnia tego samego roku dur brzuszny wykryto u kilkunastu osób, głównie z jednej posesji, co „skierowało uwagę na wodę potoku Wiercicy, do którego wpada częściowo kanalizacja miasteczka, a poza tem na studnię, z której czerpano wodę do picia"21. W skali jednego roku - 1937 - i miasta powiatowego, jakim jest Piotrków Trybunalski, również widać spore zagrożenie. W ciągu 12 miesięcy na dur brzuszny zapadło 98 osób, z czego hospitalizowano 61. Stwierdzono także dwa zgony. Podobnie było na innych terenach. Dwa lata wcześniej w całym województwie lubelskim stwierdzono ponad 1000 zachorowań i 70 zgonów. Starano się wszędzie walczyć z tą chorobą - zarówno przez prowadzenie szerokiej akcji prozdrowotnej, jak i dążenie do poprawy higieny otoczenia, sprawdzano i badano też podejrzane studnie i inne ujęcia wodne. Istotną rolę odgrywały również szczepienia ochronne - rocznie zaszczepiano w latach 30 . do około 300000 osób. Nie były jednak przymusowe, prowadzono je w wypadku wystąpienia zagrożenia. Ówczesne szczepionki nie były doskonałe, np. na ponad 220000 zaszczepionych w całym kraju w roku 1932 zachorowało na dur brzuszny 440 osób, zmarło $56^{22}$.

Nie udało się też skutecznie zwalczyć błonicy i płonicy, występujących głównie wśród najmłodszego pokolenia. Te dwie choroby występowały z jeszcze większym nasileniem niż dur brzuszny - od kilkunastu do ponad 30000 zachorowań na płonicę, zgonów od kilkuset do ponad 3000, oraz nieco mniejsza zapadalność (po kilkanaście tysięcy rocznie) na błonicę i śmiertelność tylko wyjątkowo, w dwóch latach, nieznacznie przekraczająca tysiąc przypadków. W latach 20 . i 30. nie zaobserwowano jednak znaczącej poprawy, zmniejszała się tylko systematycznie liczba zgonów, co było spowodowane zarówno szybszym dostępem do lekarza (bardzo istotny zwłaszcza w wypadku

${ }^{20}$ Sprawozdanie o stanie zdrowotnym..., dz. cyt., s. 24.

${ }^{21}$ Tamże.

${ }^{22}$ Tamże, s. 22-27; APPT, Wydział Powiatowy w Piotrkowie Trybunalskim 1917-1949 (WPPT 1917-1949), t. 1893, sprawozdanie z 1937 r.; A. Felchner, Zdrowie i zdrowotność..., dz. cyt., s. 126-127; J. Majchrzyk-Mikuła, Higiena szkolna..., dz. cyt., s. 90-91. 
błonicy), jak i lepszą terapią oraz opieką. Błonica i płonica były zwalczane głównie przez szczepienia ochronne. Stosowano je szczególnie na terenach, gdzie te choroby występowały masowo, zwłaszcza w miastach. Od 1925 r. prowadzono systematycznie szczepienia przeciwbłonicze, głównie dzieci szkół powszechnych, na terenie województw warszawskiego i lubelskiego, co spowodowało stopniowo zmniejszenie zachorowalności. W 1936 r. zarządzono obowiązkowe szczepienia przeciwbłonicze na terenach kilku województw, w tym łódzkiego, dla dzieci, które nie ukończyły 10. roku życia. W wypadku pojawienia się zachorowań rozciągano przymus szczepienia na młodzież do 15 . roku. W następnym - 1937 r. - w całym kraju zaszczepiono ponad pół miliona osób, głównie dzieci w wieku przedszkolnym i szkolnym. Nie obejmowały one jednak całej populacji, np. dzieci do 10. roku życia. Na nieco mniejszą skalę szczepiono też przeciw płonicy. Te działania profilaktyczne były przeprowadzane na koszt państwa. Brak powszechnego obowiązku szczepień, jak choćby w wypadku ospy prawdziwej, wynikał zapewne $\mathrm{z}$ wielu czynników, głównie finansowych i organizacyjnych $^{23}$.

Podobnie było w wypadku chorób, które wówczas określano jako społeczne. $Z$ nich wybrałem do szerszego przedstawienia dwie, ale należy pamiętać, że i pozostałe powodowały spore zagrożenie, zwłaszcza masowo występująca choroba oczu - jaglica. Najgroźniejszą, powodującą największą śmiertelność, była niewątpliwie grú́lica, zwłaszcza płuc. Nie była ona wówczas w pełni uleczalna, zwłaszcza przy ostrym przebiegu, a ponadto dopiero wówczas zaczęto wprowadzać pierwsze szczepionki. W Warszawie w 1925 r. powstał specjalny Komitet szczepień przeciwgruźliczych BCG. Rozszerzał on stopniowo swoją działalność na inne tereny. Biorąc pod uwagę zagruźliczenie społeczeństwa, liczba zaszczepionych noworodków do końca roku 1936, która w sumie wyniosła ponad 38 500, nie była duża i tylko w niewielkim stopniu ograniczyła rozprzestrzenianie się tej choroby. Nie ułatwiały walki z gruźlicą opisane wcześniej trudne warunki bytowe większości rodzin. Aby ukazać skalę tego zjawiska, warto przypomnieć, że z powodu tej choroby corocznie komisje poborowe odrzucały od dwudziestu kilku do ponad trzydziestu tysięcy młodych mężczyzn zgłaszających się do odbycia służby wojskowej. Nie wszyscy byli oczywiście chorzy, ale zapewne mieli jakiś kontakt z tą chorobą. Jeden z najbar-

${ }^{23}$ Dwadzieścia lat publicznej..., dz. cyt., s. 48-51; A. Felchner, Zdrowie i zdrowotność..., dz. cyt., s. 125-128, 298-301; J. Majchrzyk-Mikuła, Higiena szkolna..., dz. cyt., s. 90-95; Sprawozdanie o stanie zdrowotnym, dz. cyt., s. 28-31. 
dziej wówczas doświadczonych specjalistów wojskowych w tej specjalności, major doktor Michał Telatycki, obliczał w połowie lat 30., iż na gruźlicę zapadała 1/30 część społeczeństwa, a ponadto w ciągu pięciu lat od zarażenia umierało ok. $70 \% \mathrm{z}$ tych chorych. W naszym wojsku w latach 1922-1931 wykrywano rocznie ok. 2000 zachorowań - co stanowiło 6-7\%o stanu osobowego całej armii. A byli to przecież mężczyźni w okresie swojej najlepszej sprawności fizycznej, systematycznie, właściwie odżywiani, mający w każdej chwili dostęp do lekarza. Liczba zgonów w naszej armii nie była zbyt duża, bo większość chorych po wykryciu tej choroby była zwalniana z wojska. Na szczególną uwagę zasługuje zapadalność na gruźlicę wśród uczniów. W roku szkolnym 1925/1926 chorobę tę wykryto na przykład u ponad 8000 słuchaczy ogółu szkół średnich (ponad 6\%) i u ponad 1000 młodych osób kształcących się w seminariach nauczycielskich (prawie 4,5\%). Na terenie całego województwa lubelskiego na krótko przed wojną, w 1937 r., w ewidencji poradni przeciwgruźliczych było ponad 12600 osób, z czego czynną gruźlicę stwierdzono u ponad 3500. W tym czasie zmarło na tę chorobę ponad 1400 mieszkańców Lubelszczyzny. W powiatowym Piotrkowie Trybunalskim w 1938 r. pod opieką przychodni przeciwgruźliczej znajdowało się $\mathrm{w}$ poszczególnych kwartałach 1938 r. od ponad 1300 do 1400 osób (miasto wówczas miało niespełna 50000 mieszkańców). Wyzdrowiało w tym czasie 14 osób (zapewne ustąpiły pierwsze oznaki tej choroby), a zmarło 56. W tym ostatnim wypadku widać mimo wszystko wyraźną poprawę, jeśli porównamy liczbę zgonów w okresie pokoju z wcześniejszymi danymi z okresu wojny, czasów wielkiego niedostatku ogółu rodzin. W latach 1917-1920 na gruźlicę zmarło w tym mieście aż 635 osób. Można przypuszczać, że nie wszyscy z nich to mieszkańcy tego grodu, część zapewne stanowiły osoby zamieszkujące okoliczne tereny, niektórzy mogli być np. wojskowymi, ale i tak te dane są zatrważające. Przedstawione przykłady pokazują dobitnie, jakie zagrożenie dla polskich rodzin przez cały okres II Rzeczypospolitej stanowiła gruźlica ${ }^{24}$.

${ }^{24}$ APPT, WPPT 1917-1949, t. 1587, sprawozdanie z poradni przeciwgruźliczej z 1938 r.; Dwadzieścia lat publicznej..., dz. cyt., s. 55-59; A. Felchner, Pod znakiem Eskulapa i Marsa. Stużba zdrowia Wojska Polskiego (od jesieni 1918 r. do mobilizacji w 1939 r.), Oświęcim 2016, s. 146-149; A. Felchner, Zdrowie i zdrowotność..., dz. cyt., s. 128-132; J. Majchrzyk-Mikuła, Higiena szkolna..., dz. cyt., s. 98-101; A. Piasta, Piotrków Trybunalski w latach I wojny światowej, Piotrków Trybunalski 2007, s. 11; „Rocznik Statystyki Rzeczypospolitej Polskiej”, vol. VI, 1928 r., s. 469. Odsyłam też do Internetu. 
Zupełnie inny wymiar miały zachorowania na choroby weneryczne. Nie powodowały na ogół zgonów, przez cały wiek XX doskonalono leki, coraz skuteczniej je leczono, ale niewątpliwie dla rodzin ważny był też aspekt moralny. $\mathrm{Z}$ wówczas występujących chorób wenerycznych niewątpliwie najgroźniejszą była kiła (zwana inaczej syfilisem). Pojawiła się ona w Europie masowo w ostatnich latach XV w., najpierw na południu Półwyspu Apenińskiego, a potem stopniowo rozprzestrzeniała się na inne obszary. Przybrała wówczas postać groźnej epidemii, zabijającej w ciągu kilku-kilkunastu miesięcy osoby, które na nią zapadły. Później choroba złagodniała, ale wszelkie wielkie konflikty zbrojne przynosiły nowe, kolejne wielkie fale zachorowań. Podobnie było po I wojnie światowej. Obliczano na przykład, że tylko na terenie Polski centralnej, w przybliżeniu na obszarach byłego Królestwa Polskiego (popularnie zwanego Kongresówką), było ok. 2000000 chorych zarówno na kiłę, jak i na rzeżączkę. W okresie międzywojennym systematycznie rozbudowywano przychodnie przeciwweneryczne, prowadzono ewidencję chorych. W tym ostatnim przypadku zaobserwować można ciekawe zjawisko. Wraz ze zwiększaniem sieci lecznic, rozwojem opieki nad chorymi wenerycznie, a co za tym idzie - większą dostępnością fachowej pomocy medycznej, rosła liczba osób, u których wykryto kiłę lub rzeżączkę. Nie było wówczas sytuacji, takich jak wojna, które na ogół sprzyjają rozprzestrzenianiu się tych chorób. Można tu dla przykładu podać dane z Piotrkowa Trybunalskiego. Tylko w szpitalach miejskich, przeznaczonych dla miejscowej ludności, w latach 1914-1916 leczono 872 chorych wenerycznie. W czerwcu 1918 r. władze okupacyjne przeprowadziły spis chorych wenerycznie na obszarze byłego Królestwa Polskiego. Okazało się, że na terenie byłej guberni piotrkowskiej na statystyczne 10000 osób przypadało 330 chorych $(3,3 \%)$. Byli to oczywiście głównie pacjenci będący w ewidencji różnych placówek służby zdrowia. Zapewne prawdziwa skala tego niepokojącego zjawiska była dużo większa. Wraz z upływem lat zagrożenie ze strony tych chorób, jak wspomniałem, nie mijało. Dla przykładu w Piotrkowie Trybunalskim tylko w latach 1926-1928 stwierdzono ogółem 80 nowych zachorowań na kiłę, 88 na rzeżączkę i 3 na wrzód weneryczny. Na specjalistyczne oddziały miejscowych szpitali skierowano 45 chorych wenerycznie. Zdawano sobie sprawę z zagrożeń, jakie niesie prostytucja, dlatego też w omawianym okresie wielokrotnie badano kobiety zajmujące się tym procederem - ogółem dokonano aż 3637 takich oględzin. Jak wspomniałem, liczba chorych nie malała. W dniu 31 grudnia 1938 r. w dwóch przychodniach prze- 
ciwwenerycznych w Piotrkowie Trybunalskim (w tym jedna w ośrodku zdrowia) oraz w czterech na terenie powiatu (wszystkie znajdowały się w lokalnych ośrodkach zdrowia): w Bełchatowie, Kamieńsku, Sulejowie i w Wolborzu, w ewidencji było ogółem 200 chorych na kiłę, 38 pacjentów ze zdiagnozowaną rzeżączką i $2 \mathrm{z}$ wrzodem wenerycznym. W ostatnim kwartale tego roku udzielono w tych przychodniach ogółem 1357 porad lekarskich i dokonano 1266 różnych zabiegów. Jak rozwijała się walka z tymi groźnymi dla ogółu rodzin chorobami, świadczą również dane ogólnopolskie. W 1923 r. w całym kraju było zaledwie 14 specjalistycznych poradni przeciwwenerycznych (poza przyszpitalnymi), które miały pod opieką zaledwie 8640 pacjentów. Po 10 latach działały już 134 takie placówki, liczba pacjentów wzrosła do ponad 23000 , udzielono też ponad 150000 porad. W roku 1937 liczba przychodni (głównie w ośrodkach zdrowia) wzrosła do 507, pacjentów do ponad 176000 , porad do prawie 95000 . To pokazuje z jednej strony, jak dzięki rozwojowi lecznictwa coraz więcej chorych korzystało ze specjalistycznej pomocy medycznej, miało możliwość wyzdrowienia, a z drugiej olbrzymią skalę tego zjawiska, tak groźnego dla polskich rodzin, w wielu zresztą aspektach ${ }^{25}$.

Ostatnią istotną kwestią, którą warto poruszyć, jest problematyka zdrowia i umieralności niemowląt. Jak informują liczne obecnie strony internetowe, aktualne dane (poniżej 3\%o śmiertelności, licząc wszystkie urodzenia) lokują Polskę w środku różnych tabel. Uważa się, że niskie wskaźniki są potwierdzeniem zarówno zamożności, wysokiego poziomu wykształcenia ogółu społeczeństwa, jak i dobrej organizacji służby zdrowia danego państwa. Kluczową sprawą jest roztoczenie pełnej opieki nad rodziną, a zwłaszcza przyszłą matką, od pierwszych miesięcy ciąży. W ubiegłym stuleciu nastąpił olbrzymi spadek umieralności niemowląt. Wskaźniki z okresu międzywojennego, podawane w ówczesnych dokumentach, wydają się obecnie szokująco wysokie. W oficjalnym sprawozdaniu z 1939 r. informowano i oceniano: „umie-

${ }^{25}$ APPT, Akta miasta Piotrkowa 1746-1945, t. 2570, informacja obejmująca lata 1925-1928; Dwadzieścia lat publicznej..., dz. cyt., s. 63-68; A. Felchner, Zdrowie i zdrowotność..., dz. cyt., s. 135-139. Na temat różnych porównań dotyczących kwestii zdrowotności i zachorowalności w Piotrkowie Trybunalskim odsyłam też do własnego artykułu: Doświadczenie choroby przez społeczeństwo II Rzeczypospolitej na przykładzie Piotrkowa Trybunalskiego i powiatu piotrkowskiego, [w:] B. Płonka-Syroka, M. Skrzypek (red.), Doświadczenie choroby $w$ perspektywie badań interdyscyplinarnych, Wrocław 2010, s. 529-546; A. Piasta, dz. cyt., s. 125-134. Szerzej na temat kiły pisze w bardzo ciekawej książce C. Quétel, Niemoc z Neapolu czyli historia syfilisu, Wrocław, Warszawa, Kraków 1991 r. Poświęcono tam także całe fragmenty rozważaniom nad sytuacją, gdy w rodzinie pojawił się ktoś - najczęściej mąż i ojciec - zarażony kiłą. 
ralność nadmierna matek i dzieci jest w Polsce zjawiskiem powszechnym. Aby zdać sobie sprawę z tego wystarczy porównać kilka liczb, dotyczących tego zagadnienia na terenie Europy Zachodniej z jednej strony, a Polski z drugiej. A więc umieralność niemowląt w ciągu pierwszego roku życia wynosiła w roku 1930 na sto urodzin żywych w miastach holenderskich tylko 4,1, w Wiedniu - 7,1, w Pradze Czeskiej - 9,0, a w Warszawie -11,8. W tym samym roku przeciętna umieralność niemowląt dla całej Polski wynosiła 14,3\%"26. Należy dodać, że w okresie dwudziestolecia międzywojennego obserwowano w naszym kraju niewielką poprawę w tym zakresie. O ile w $1927 \mathrm{r}$. wspomniany wskaźnik wynosił aż $15,1 \%$, o tyle pod koniec lat 30 . wahał się między 12,8 a 13,6\%. Ważną kwestią był rozwój różnych instytucji mających pomagać rodzinom, a szczególnie matkom i najmłodszym, nowo narodzonym. U początków niepodległości, w $1918 \mathrm{r}$., w przybliżeniu na obszarze późniejszej II Rzeczypospolitej działało zaledwie 25 przychodni dla matki i dziecka, nie licząc przyszpitalnych. Należy jednak pamiętać, że w przeciętnym powiatowym szpitalu nie było na ogół oddziałów pediatrycznych. W połowie okresu międzywojennego, w 1929 r., było ich już 231, a w 1937 r. - 570. Widać tutaj wyraźnie, jak ważną rolę zaczęły odgrywać systematycznie tworzone ośrodki zdrowia, gdyż większość tych placówek działała w ich ramach. Stale też rosła liczba osób pod ich opieką - na przykład z ponad $100000 \mathrm{w}$ roku 1931 do ok. 207000 w 1937 r. Sieć placówek dla matki i dziecka była uzupełniana przez społeczne czy samorządowe instytucje, jak np. „Kropla mleka”, zaopatrujące najmłodsze pokolenie w odpowiednio przygotowany i właściwy pokarm. Powstawały też i inne - np. w roku 1938 uruchomiono w Piotrkowie Trybunalskim Poradnię Świadomego Macierzyństwa. $Z$ tą tematyką nierozerwalnie wiąże się zagadnienie trochę niejako marginalne (biorąc pod uwagę liczby bezwzględne w sprawozdaniach), ale o bardzo ważnym wydźwięku społecznym i moralnym, czyli kwestia nieślubnego macierzyństwa. Obecnie mamy zupełnie inny pogląd na te kwestie, narodziło się np. pojęcie „partnerskiego związku”, „partnerki” i „partnera”, coraz więcej dzieci rodzi się $\mathrm{w}$ takich nieformalnych $\mathrm{z}$ punktu widzenia prawa rodzinach. W okresie II Rzeczypospolitej było to spychane na margines społeczny, tragiczne losy dotykały często dzieci urodzone przez niezamężne kobiety. Zupełnie inaczej i bardzo tragicznie wyglądały też dane dotyczące umieralności takich niemowląt. Według badań przedwojennych materiałów prowadzonych przez T. Dworacką najwięcej dzieci nieślubnych było

\footnotetext{
${ }^{26}$ Dwadzieścia lat publicznej..., dz. cyt., s. 68.
} 
w dużych miastach, na czele ze stolicą. W Warszawie rodziły je głównie kobiety, które w poszukiwaniu pracy przyjechały ze wsi (ponad 63\%) i małych miasteczek (12\%). Rodowite warszawianki stanowiły niecałe $15 \%$ matek nieślubnych dzieci. O ile promil zgonów niemowląt poniżej pierwszego roku życia w stolicy spadał ze $110 \mathrm{w} 1925 \mathrm{r}$. do prawie $79 \mathrm{w} 1935 \mathrm{r}$., o tyle w wypadku noworodków pozamałżeńskich promil ten wynosił odpowiednio aż 776 i spadł do 470. Oznaczało to, że początkowo, w latach 20 . XX w., w pierwszym roku życia umierało ok. 3/4 takich dzieci, a pod koniec okresu międzywojennego już tylko, czy raczej aż, nieco poniżej połowy. Spowodowane to było wieloma względami, jedną z najważniejszych przyczyn była mała dbałość o nienarodzone dziecko przez ciężarną kobietę, często zmuszoną ukrywać ciążę. Wiele z tych dzieci było porzucanych, zwłaszcza w dużych miastach. W Warszawie np. w latach 1934-1938 porzucano rocznie ok. 500 dzieci, w Wilnie ok. 200, ale np. w Kielcach, Piotrkowie Trybunalskim czy Włocławku były to już tylko pojedyncze przypadki. Dane te pokazują cały dramatyzm takich sytuacji, tragiczny los wielu dzieci i mało chwalebną kartę z dziejów przedwojennej Rzeczypospolitej ${ }^{27}$.

Na zakończenie należy podkreślić, że odradzająca się po rozbiorach Polska borykała się z wieloma trudnościami. Jednymi z najważniejszych dla ówczesnych rodzin były zagrożenia ze strony różnych chorób. Przez całe dwudziestolecie międzywojenne starano się poprawić i usunąć najważniejsze zagrożenia $\mathrm{w}$ tym zakresie. W wielu wypadkach to się udawało, postęp był widoczny. W niektórych kwestiach, z różnych przyczyn - zarówno ekonomicznych, jak i np. braku możliwości skutecznego leczenia czy zbyt wolnej zmiany ugruntowanych, złych nawyków w społeczeństwie, obserwowano niewielkie zmiany lub nawet stagnację.

${ }^{27}$ Tamże, s. 68-71; T. Dworacka, Nieślubne macierzyństwo jako problem demograficzny $i$ społeczny w II Rzeczypospolitej w ujęciu prasy polskiej z lat 1918-1939, [w:] B. Płonka-Syroka (red.), Gra możliwości. Studia z historii medycyny i farmacji XIX i XX wieku. Studia humanistyczne Wydziału Farmaceutycznego Akademii Medycznej we Wrocławiu, Wrocław 2011, s. 139-163; A. Felchner, Zdrowie i zdrowotność..., dz. cyt., s. 243-256; Sprawozdanie o stanie zdrowotnym..., dz. cyt., s. 5-6. W Internecie znajduje się wiele różnych informacji na te tematy, wystarczy w wyszukiwarce wpisać odpowiednie, interesujące nas hasło. 


\section{Bibliografia}

Archiwum Państwowe w Piotrkowie Trybunalskim, zespoły:

- Akta miasta Piotrkowa 1746-1945.

- Starostwo Powiatowe Piotrkowskie 1919-1939.

- Wydział Powiatowy w Piotrkowie Trybunalskim 1917-1949.

Brzoza C., Wielka historia Polski. Polska w czasach niepodległości i drugiej wojny światowej (1918-1945), vol. 5, Kraków 2003.

Chwalba A., Historia Polski 1795-1918, Kraków 2000.

Chwalba A., Samobójstwo Europy. Wielka wojna 1914-1918, Kraków 2014.

Ciesielska M., Tyfus groźny zabójca i cichy sprzymierzeniec, Warszawa 2015.

Determinanty chorób i zdrowia - PZWL, www.wydawnictwopzwl.pl/ download/229360100.pdf.

Dwadzieścia lat publicznej służby zdrowia w Polsce odrodzonej 19181938, wprowadzenie E. Piestrzyński, Warszawa 1939.

Dworacka T., Nieślubne macierzyństwo jako problem demograficzny i społeczny w II Rzeczypospolitej w ujęciu prasy polskiej z lat 1918-1939, [w:] B. Płonka-Syroka (red.), Gra możliwości. Studia $z$ historii medycyny i farmacji XIX $i \mathrm{XX}$ wieku. Studia humanistyczne Wydziału Farmaceutycznego Akademii Medycznej we Wrocławiu, Wrocław 2011.

Dziennik Urzędowy Województwa Łódzkiego, 1922 r., nr 32.

Felchner A., Doświadczenie choroby przez społeczeństwo II Rzeczypospolitej na przykładzie Piotrkowa Trybunalskiego i powiatu piotrkowskiego, [w:] B. Płonka-Syroka i M. Skrzypek (red.), Doświadczenie choroby w perspektywie badań interdyscyplinarnych, Wrocław 2010.

Felchner A., Pod znakiem Eskulapa i Marsa. Stużba zdrowia Wojska Polskiego (od jesieni 1918 r. do mobilizacji w 1939 r.), Oświęcim 2016.

Felchner A., Z problematyki zwalczania chorób zakaźnych w Piotrkowie i powiecie piotrkowskim w latach 1919-1921 - zagadnienia medyczne i społeczne, [w:] B. Płonka-Syroka (red.), Choroba, jako zjawisko społeczne i historyczne. Studia z Dziejów Kultury Medycznej, Wrocław 2001.

Felchner A., Zdrowie i zdrowotność piotrkowian. Z problematyki zdrowotności mieszkańców Piotrkowa Trybunalskiego i powiatu piotrkowskiego na tle całego kraju (od końca lat 20-tych do początków 70-tych XX wieku), Wrocław 2006. 
Glinka W., Pamiętnik z wielkiej wojny, vol. I-IV, Warszawa 1927.

Grabski W., Żabko-Potopowicz A., Ratownictwo społeczne w czasie wielkiej wojny (1914-1918), Warszawa 1932.

Kołodziejczyk R. (red.), Społeczeństwo polskie w dobie I wojny światowej $i$ wojny polsko-bolszewickiej 1920 roku, Kielce 2001.

Konstytucja Rzeczypospolitej Polskiej z 17 marca 1921 r., [w:] R. Szaflik (oprac.), Źródła do dziejów Polski w XIX i XX wieku. Lata 1918-1939. Polska Niepodległa. Wybór tekstów źródłowych, vol. 3, Pułtusk 1998.

Kopczyński M., Wpływ I wojny światowej na poziom życia w Królestwie Polskim w świetle mierników biologicznych, „Przegląd Historyczny" 2001, vol. XCII, nr 3.

Kulik H., Feminizacja zawodu lekarza w Polsce, [w:] R. Meissner (red.), Medycyna i farmacja XIX i XX wieku, Poznań 2007.

Kulik H., Stan zdrowia i lecznictwo wsi polskiej w okresie XX międzywojennego, [w:] R. Meissner, Medycyna i farmacja w XIX $i$ XX wieku, Poznań 2007.

Kuźma-Markowska S., Zaraza u bram Nowego Jorku: reakcja amerykańskiej opinii publicznej na epidemię tyfusu w Polsce po I wojnie światowej, „Medycyna Nowożytna. Studia nad Kulturą Medyczną” 2014, vol. 20, z. 1.

Łobocki M., Teoria wychowania w zarysie, Kraków 2009.

Majchrzyk-Mikuła J., Higiena szkolna na Lubelszczyźnie w latach 1918-1939 na tle całego kraju, Piotrków Trybunalski 2013.

Majchrzyk-Mikuła J., Zdrowie, a jakość życia dziecka $w$ domu rodzinnym $w$ okresie międzywojennym, „Wychowanie w Rodzinie” 2016, vol. XIV, nr 2.

Mały Rocznik Statystyczny Polski wrzesień 1939-czerwiec 1941, Londyn 1941.

Okoń W., Nowy słownik pedagogiczny, wyd. czwarte, Warszawa 2004.

Opieka społeczna. Zbiór ustaw i rozporzadzeń, opr. S. Grochowski, E. Chwalewik, Warszawa 1929.

Piasta A., Piotrków Trybunalski w latach I wojny światowej, Piotrków Trybunalski 2007.

Prokl K., Kowalczewski J. (red.), Polskie prawo sanitarne, zbiór ustaw, instrukcji, okólników i pism okólnych z lat 1918-1935, vol. 1-2, Warszawa 1935-1936.

Quétel C., Niemoc z Neapolu czyli historia syfilisu, Wrocław, Warszawa, Kraków 1991.

Rocznik Statystyki Rzeczypospolitej Polskiej, vol. VI, 1928. 
Roszkowski W., Historia Polski 1914-2005. Nowe uaktualnione wydanie, Warszawa 2006.

Różańska-Gambal B., Występowanie epidemii ospy prawdziwej na świecie od czasów starożytnych po wspótczesne, „Medycyna Nowożytna. Studia nad Kulturą Medyczną" 2008, vol. 15, z. 1-2.

Sprawozdanie o stanie zdrowotnym Rzeczypospolitej Polskiej oraz o działalności władz $i$ instytucji zdrowia publicznego $w$ latach 1932-1933, Warszawa 1935.

Urbanek M., Profesor Weigl i karmiciele wszy, Warszawa 2018.

Więckowska E., Lekarze, jako grupa zawodowa w II Rzeczypospolitej, Wrocław 2004.

Więckowska E., Walka z ostrymi chorobami zakaźnymi w Polsce w latach 1918-1924, Wrocław 1999.

Wnęk J., Pandemia grypy hiszpanki (1918-1939) w świetle polskiej prasy, „Archiwum Historii i Filozofii Medycyny” 2014, vol. 77.

Wojciechowski S., Moje wspomnienia, Warszawa-Lwów 1938.

\section{Summary}

\section{The Family in the Second Polish Republic - The Main Dangers of Diseases}

The period between 1918 and 1939 is extremely important not for Poland but also for Polish families of that period. After about 150 years of partitions the families could again live and bring up their children in an independent and free country. The times were judged and described in different ways in the past. From 1945 until the changes of the economic mode originated in 1989 the times were very negatively perceived by the imposed government of that period. Within the last, almost thirty years, in newspapers those events were presented sometimes too positively. The time passing and new publications describing social life of whose who lived ninety or a hundred years ago allow to explore in deep and diversify the scope of the research. The issues are also meaningful for contemporary families. They concern extremely important problems - for instance, bringing up and educating the forthcoming generations while preserving traditions and respecting the things which had already been achieved. Obviously, the difficult or controversial issues should not be avoided at any stage of the discussion. One of the elements connected with education are health and illness issues concerning also the recent past. The defeat of the imperialist countries after World War I was used by Polish society. With the support of the victorious allies Poland was reborn as an independent, sovereign country. In spite of the fact that our country formally did not participate in warfare of 1914-1918 still it became the area of fierce battles and fighting. Within the first years of the young country until the end of the Third Silesian Uprising in spring 1921, the situation constantly worsened. This period 
was extremely difficult for the society. One of the most frequently problems that the families had to face were massive infectious illness outbreaks (for instance, typhoid fever, smallpox or cholera) or social illness outbreaks, like tuberculosis or venereal diseases. Only in 1920s did the negative health situation of the families improve. The great world economic crisis which started in 1929 and finished in Poland after five years impaired the issues connected with health of general public. Because of financial problems the activity of, for example, school health care system activity was limited. The last two years of the Second Polish Republic brought an improvement of the situation as far as health issues are concerned. Infant mortality rate was decreasing. The net of health centers developed and there were the centers responsible for the mother and child health care, school hygiene and the control of the most dangerous social diseases - tuberculosis, trachoma, venereal diseases. Immunization of the youngest was introduced to a bigger scale. The number of doctors educated at five Polish universities increased and the health state of the society improved. The discussions concerning the improvement of health care system continued. The disputes also referred to the school medicine which was better organized at that time.

It is possible to claim that by presenting the above issues the important elements from family life in the Second Polish Republic will be reminded but also some conclusions concerning contemporary period can be drawn. 